\title{
INTERPLANT TRANSFER AND TERMINATED WORKERS: A CASE STUDY
}

\author{
DAVID B. LIPSKY
}

$\mathrm{O}$ N MARCH 7, 1962, the General Foods Corporation announced that four plants in its Jello-O Division would be shut down over the ensuing two or three year period and their operations consolidated in a new facility to be built on a site to be determined. About 1,800 workers were threatened with displacement by the corporation's decision.

The four affected plants were the Minute Rice and Tapioca plant of Orange, Massachusetts; the original Jello-O dessert plant of LeRoy, New York; the Franklin Baker Coconut plant of Hoboken, New Jersey; and the Walter Baker Chocolate plant in Dorchester, Massachusetts.

After deciding to shut down the plants,

Following its decision to close four plants and transfer their operations to a new location, the General Foods Corporation offered jobs in the new plant to all 1,800 affected employees and payment of their transfer expenses. To those electing not to transfer, the Corporation offered severance pay. Less than a fourth of employees transferred to the new location. This study analyzes in detail the characteristics of the movers and nonmovers and the subsequent employment experience of the latter. It concludes that those workers who most needed the job and income protection offered by the transfer plan were least likely to take advantage of the opportunity.

David B. Lipsky is assistant professor, New York State School of Industrial and Labor Relations, Cornell University. He expresses thanks for advice to Charles A. Myers, Douglass V. Brown, Abraham J. Siegel, and John Dunlop and to many persons now or formerly associated with General Foods Corporation, especially Harry Chandler.-EDIToR the General Food Corporation instituted an "interplant-transfer system." It offered to all of the affected workers-blue-collar and white-collar alike-an opportunity to relocate to the new plant at company expense. This article concentrates on two facets of the experience of workers affected by the plant shutdowns. After briefly describing the nature of the interplant-transfer system, the author discusses certain correlates of relocation, i.e., factors which seem to be related to whether a worker elected to terminate or to transfer with the company to its new plant. Second, the labor-market experience of a sample of Walter Baker workers who elected termination is examined.

The major findings of this study are that corporate relocation expenditures tended to benefit those workers who would have been affected least adversely by displacement and that workers who would have benefited most from the relocation opportunity were least likely to elect it. This implies that from the point of view of the workers, the programs might have been recast to improve the distribution of the amount of assistance the company was willing to offer the affected workers.

\section{The Nature of the Samples}

The data for this study were obtained from an interview schedule adminis- 
tered by the author to 116 terminated Walter Baker workers and 215 workers who had relocated to the new plant.

At the time this study was begunSeptember 1964-the Walter Baker plant was still employing 304 workers out of a peak work force of 825 . At that point, there were 230 workers who had been eligible to transfer, but who had elected to stay in the Boston area. It was decided to interview as many of the 230 as possible. Of the 304 still employed, another 230 were to be terminated over the next eight months. Therefore, the number of terminations as of September 1964 represented only one half of the number who eventually were to be terminated at Walter Baker.

Unfortunately, time and cost constraints, as well as the inaccessibility of many of the terminated workers, permitted usable, completed interviews to be obtained from only 116 former Walter Baker employees. Fortunately, complete access to company personnel records allowed a check to be made on both the reliability of the responses of those interviewed and the representativeness of the sample, i.e., whether the 116 in the sample were representative of the 460 total terminations at Walter Baker.

The overwhelming majority of those interviewed supplied information which checked remarkably well with company records. The deviation on any of five items cross-checked was extraordinarily slight. ${ }^{1}$ In addition, the interviewed workers were compared with all termi-

\footnotetext{
${ }^{2}$ The 5 items were date of birth, years of seniority, weekly wage or salary, amount of severance pay, and years of school. The strongest tendency exhibited was a predilection on the part of a few individuals to overstate the number of years they had spent in school. The net aggregate error on this item, however, was estimated to be no greater than plus $5 \%$.
}

nations on four items and were found to be a representative selection. ${ }^{2}$

Interviews were obtained from the relocated workers in June 1965 . Workers were administered a confidential, fixed-choice questionnaire on company premises. Of the 215 workers interviewed, 137 had transferred from the Walter Baker plant and are the focus of comparisons with terminated Walter Baker workers. The 137 workers represented more than 73 percent of those Walter Baker employees who had relocated to the new plant.

\section{The Relocation Opportunity}

On September 5, 1962, six months after the shutdown notice, the Corporation announced that the site for the plant would be Dover, Delaware. By February 1964, the new plant was nearly completed and the manufacturing process was begun. Some Walter Baker workers were transferred to the new facility as early as October 1963. Terminations began early in 1964 and were continued through the spring of 1965 when the Walter Baker plant, after two centuries of manufacturing chocolate, was closed permanently.

In the months following the initial announcement of the closing of the four plants, General Foods developed a set of policies designed to cushion the impact of the shutdowns on the workers. These policies included providing to all workers a generous opportunity to relocate to the new plant-a rather novel approach, but indicative of the direction taken by many companies in recent years. ${ }^{3}$ It should be noted that

\footnotetext{
${ }^{2}$ Years of school was not an item used to check the representativeness of the sample, for the reason cited in fn. $I$.

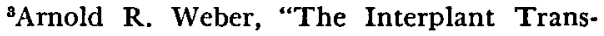
fer of Displaced Employees," in Gerald G. Somers, et al., eds. Adjusting to Technological Change
} 
Table 7. Walter Baker Transfers and Terminations, March 1962 to April 1965.

\begin{tabular}{|c|c|c|c|c|c|c|}
\hline & \multicolumn{2}{|c|}{ Hourly Employees } & \multicolumn{2}{|c|}{ Salaried Employees } & \multicolumn{2}{|c|}{ Total } \\
\hline & Number & Percent & Number & Percent & Nimber & Percent \\
\hline Terminations after 3 & 376 & 72.6 & 84 & 27.4 & 460 & 55.8 \\
\hline Transfers to Dover... & 69 & 13.3 & 118 & 38.4 & 187 & 22.7 \\
\hline Transfers to other General Foods units. & 5 & 1.0 & 6 & 2.0 & 11 & 1.3 \\
\hline Others*.. & 68 & 13.1 & 99 & 32.2 & 167 & 20.2 \\
\hline Total employment-3/62. & 518 & 100.0 & 307 & 100.0 & 825 & 100.0 \\
\hline
\end{tabular}

"Includes: (a) retired and deceased, but not including those who elected early retirement at their termination date; (b) temporary and casual employees, not eligible for severance pay or transfer to Dover; and (c) quits, resignations, discharges, and layoffs.

while unions represented workers at both the Walter Baker and Franklin Baker plants, they played virtually no role in the development of the interplant-transfer system. The Corporation was apparently motivated by two factors in developing policy: (1) the desire to maintain the "good will" of the communities in which plants were being closed, and (2) the need to insure an adequate supply of labor at the new plant-General Foods believed that it would be difficult to recruit a quality work force in the small community of Dover.

Briefly, the Corporation guaranteed a job at the new Dover plant to all 1,800 affected employees. An employee electing transfer would receive one week off with pay at the time of his move and reimbursement up to $\$ 1,000$ for transfer expenses, including the total cost of packing and carting his house-

(New York: Harper and Row, Publishers, 1963), pp. 95-143. See also Norman M. Bradburn, Interplant Transfer: The Sioux City Experience (Chicago, Ill.: National Opinion Research Center, University of Chicago Press, May 1964); George P. Shultz and Arnold R. Weber, Strategies for the Displaced Worker (New York: Harper and Row, Publishers, 1966); and U.S. Bureau of Employment Security (BES), Work Force Adjustments to Technological Change: Selected Em. ployer Procedures (Washington: G.P.O., January 1963), Bulletin No. E-215. hold furniture, travel expenses (meals, lodging, etc.), and also most incidental expenses. As an example of the last, General Foods covered such items as real estate brokerage fees, telephone installation costs, alteration of rugs and draperies, and even prorated expenses of unused portions of an automobile license plate and operator's license. In addition, the Corporation provided extensive counseling to employees, especially on housing in the Dover area. (The Corporation would purchase the homes of salaried workers if they wished but not of hourly employees.) Every employee, whether he transferred or not, was offered a free trip to Dover to survey the community and the new plant.

For those who elected termination, the Corporation offered a generous severance-pay plan. Severance benefits were based on age and length of service. Terminated Walter Baker employees received, on the average, about $\$ 1,500$. General Foods also provided employment counseling to terminated workers, although it is generally agreed (even by corporate management), that such counseling was more or less perfunctory.

Table 1 shows that of 825 workers employed at Walter Baker in March 1962, 187 (22.7 percent) transferred to 
Dover. However, only 13.3 percent of the hourly employees elected transfer, compared to 38.4 percent of the salaried employees. The picture is similar when all four plants are considered. Of the 1,800 employees at the four plants, 423 , or 23.5 percent, transferred to Dover. But only 179, i.e., 14.2 percent of all hourly employees transferred, compared to 253 , or 42.3 percent of all salaried workers.

\section{Some Correlates of Relocation}

Table 2 contrasts, in summary fashion, terminated Walter Baker workers with relocated workers on several selected variables. A basic determinant of relocation was occupational status: professional, technical, managerial, and skilled workers were much more likely to move than operatives, laborers, and clerical and sales people. A white-collar/bluecollar distinction is not quite appropriate here, since foremen and other craftsmen were, in a relative sense, twice as likely to move as clerical and sales personnel.

Sex was apparently the other variable most strongly related to moving. About 10 percent of those who moved to Dover were women; they were usually either the wives of workers also transferring to Dover or single "career" women.

There was a fairly clear inverse relationship between age and geographic mobility. Older workers tended to elect termination. However, this relationship was not as strong as is typically the case. ${ }^{4}$ In fact, the difference in mean

\footnotetext{
'Herbert S. Parnes, Research on Labor Mobility (New York: Social Science Research Council, 1954), pp. 104-105. See also John B. Lansing, et al., The Geographic Mobility of Labor: $A$ First Report (Ann Arbor, Mich.: Survey Research Center, 1963), pp. 55-60; U.S. Department of Labor, Mobility and Worker Adaptation to Economic Change in the United States
}

Table 2. Correlates of Relocation: A Comparison of Terminated and Transferred Workers.

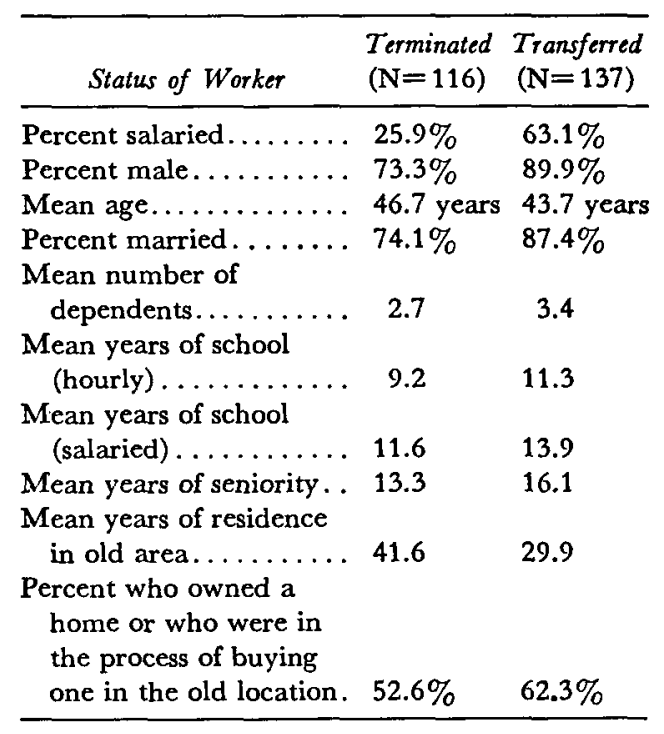

age of terminated and relocated workers is not statistically significant.

Apparently, an interplant-transfer system of the General Foods type will induce a larger number of older workers to move to a new location than might be expected, given the mobility propensities of older workers. ${ }^{5}$

Indeed, there are a number of surprises on Table 2. The proportion of married workers was higher among the relocated workers than among the terminated. Moreover, the relocated workers had, on the average, more dependents than the terminated workers. Also there is evidence to indicate a working wife was not a barrier to the transfer of a General Foods worker. These results contradict popularly held notions about correlates of mobility.

Most surprising, perhaps, is the finding that the proportion of homeowners (Manpower Research, Bulletin No. 1, July 1963), p. 22.

${ }^{\circ}$ U.S. Department of Labor, Mobility and Worker Adaptation. 
among the relocated workers was higher than the proportion among terminated workers. Even when the samples are broken down by additional variables (for example, occupation), this finding is true. There are two factors which might explain this unusual result: (1) General Foods' provision of extensive aid and assistance to the homeowner who elected to transfer, and (2) the lack of rental opportunities in the Dover area which might serve as a disincentive to move for those workers who had a preference for renting.

On other variables, General Foods transfers tended to be more like typical migrants. For example, relocated workers were more educated than terminated workers. In relative terms, about twice as many relocated workers as terminated workers had gone beyond high school. Also, those who transferred had lived fewer years in their old area than terminated workers. Yet in absolute terms, the relocated workers had been strongly attached to their former communities, averaging about thirty years of residence. Most of the movement in this country is done by a small proportion of the people, and they, consequently, tend to be short-term residents of the communities from which they move. Therefore, in terms of years of residence in the old area, the relocated worker was an extremely atypical migrant.

It is clear that seniority was an important correlate of relocation. Only by transferring to Dover could the General Foods worker retain the privileges attendant on long service. Seniority also can be viewed as a measure of the worker's loyalty to the company. The plant relocation was a test of his attachment to the company vis-à-vis his attachment to his community. There was a tendency for long years of service with the com- pany to dominate long years of residence in the old area, and thus for seniority to be a crucial variable among those found to be associated with relocation.

A number of other variables which might help distinguish "movers" from "stayers" were examined but proved to be insignificant. For example, family income and asset-and-debt position were not related significantly to relocation.

\section{A Differing Pattern of Mobility}

While no hard and fast conclusions can be drawn on the basis of evidence presented here, it appears that an interplant-transfer system promotes a pattern of mobility which differs from the standard as determined by many other studies of mobile workers. The relocated or transferred worker is a mobile worker only in the sense that he changes his area of residence. Transferred workers typically do not change their employer, industry, occupation, labor force status, or even their job assignment. In a sense, the terminated worker can be considered more "mobile" than the transferred worker. The terminated worker reenters the labor market or leaves the labor force completely. He must, necessarily, change employers, and this move probably will mean a change of industry and often a change of occupation. Are these changes of a higher or lower order of mobility than geographic movement? Who faces greater uncertainty and risk, the terminated worker or the relocated worker? One usually associates risk taking with the migrant-but is this really true of the General Foods worker?

The typical migrant changes not only his place of residence but also his employer, his industry, and very often his occupation. "Labor mobility responds to 
opportunity," 6 and this has been found true for migrants. For example, migration rates are higher for the unemployed than for the employed. ${ }^{7}$ But is it true of the transferred worker? Does the transferred worker seek economic opportunity-or economic security?

In the United States in 1964, the year when most General Foods workers transferred to Dover, approximately $38 \mathrm{mil}$ lion people changed their place of residence. Of this number, approximately 6.1 million moved between states, representing 3.3 percent of the total population. ${ }^{8} \mathrm{~A}$ study by the Survey Research Center of the University of Michigan revealed that of the total number of moves made within the 1958-1962 period, 16 percent were "triggered" by a transfer or reassignment. ${ }^{\circ}$ Assuming that this percentage is valid for 1964 , it appears that just under one million people changed their state of residence in that year as a result of a job transfer.

There is evidence that interplanttransfer systems have grown in importance in recent years. Such plans have now been incorporated in several im. portant collective bargaining agreements -most notably between the Steelworkers and the steel industry, International Harvester and the United Automobile Workers, and Ford, Chrysler, and Gen-

"Gladys L. Palmer, "Interpreting Patterns of Labor Mobility," in E. Wight Bakke, et al., eds., Labor Mobility and Economic Opportunity (New York: The Technology Press of M.I.T. and John Wiley and Sons, Inc., 1954), p. 62.

${ }^{\tau}$ Seymour L. Wolfbein, Employment and $\mathrm{Un}$ employment in the United States (Chicago, Ill.: Science Research Associates, 1964), p. 222.

${ }^{8}$ U.S. Bureau of the Census, Statistical $A b$ stract of the United States, 87th ed. (Washing. ton: G.P.O., 1966), p. 32. The "year" is actually the twelve-month period between March 1964 and March 1965.

${ }^{9}$ Lansing, Geographic Mobility of Labor, p. eral Motors and the UAW.10 There is no way of knowing precisely how many companies, such as General Foods, have unilaterally instituted such systems. However, a 1964 survey by the American Management Association revealed that 256 of 329 responding companies had "definite policies covering benefits for employees transferred to other locations," and that 77 percent of these policies had been developed in the ten-year period just prior to the survey. ${ }^{11}$

The growth of interplant-transfer systems in American industry may portend an increase in the number and proportion of moves resulting from company relocations. If the results of this study are any indication, the characteristics of migrants in general may be somewhat changed as a result of the larger number of interplant transfers.

\section{Unemployment Experience of the Terminated Workers}

Every major study of displaced or terminated workers has been concerned with specifying personal factors which

\footnotetext{
${ }^{10}$ Weber, "Interplant Transfer of Displaced Employees," pp. 95-143; Richard A. Beaumont and Roy B. Helfgott, Management, Automation and People (New York: Industrial Relations Counselors, 1964), pp. 66-81. For the steelworker plan, see United Steelworkers of America, AFL. CIO, and United States Steel Corporation, Agreement, September 1, 1965, Sections 13M and $13 \mathrm{~N}$.

${ }^{11} \mathrm{~K}$. K. White, Reimbursing Personnel for Transfer and Relocation Costs (New York: American Management Association, 1964), AMA Research Study 67. It should be noted that most policies applied to individuals or small groups transferring. It is not clear that the same transfer policies would be used in the event of one or more plant shutdowns involving large numbers of employees. Furthermore, it is clear that blue-collar personnel do not receive the same consideration as do white-collar personnel. "In fact, only half of the respondents include (the rank and file) in their policies; but when they are covered they generally receive comparable benefits" pp. 13-15.
} 
are important in the reemployment of such workers.12 In this section the terminated Walter Baker workers will be analyzed with the same aim in mind. One or two factors, such as alternative sources of income and severance pay, not extensively analyzed in other studies, are considered here. Also, an attempt has been made to carry the analysis farther than has been done in most previous studies. Linear regression analysis has been applied in an effort to weigh more precisely the factors important in the reemployment of terminated workers. The results are given later. First, a more traditional analysis of the variables is presented.

It must be kept in mind that a precondition for the successful reemployment of any individual is an adequate level of demand for labor in the market in which job search takes place. In 1964 and 1965 the Boston labor market area was classified by the Bureau of Employment Security as an area of "moderate unemployment," i.e., unemployment was in the 3.0 percent to 5.9 percent range..$^{13}$ The actual unemployment rate for the Boston area was estimated to be 4.1 percent in November 1964; 5.1 percent in January 1965; and 4.7 percent in March 1965.14 It was in the November

${ }^{12}$ See the summary study by William Haber, et al., The Impact of Technological Change (Kalamazoo, Mich.: The W. E. Upjohn Institute for Employment Research, 1963). Two significant studies not summarized by Haber, et al., are Richard C. Wilcock and Walter $\mathbf{H}$. Franke, Unwanted Workers (Glencoe, Ill.: The Free Press, 1963) and Irvin Sobel and Hugh Folk, "Labor Market Adjustment by Unemployed Older Workers," in Arthur M. Ross, ed., Employ. ment Policy and the Labor Market (Berkeley and Los Angeles: University of California Press, 1965), pp. 333-357.

${ }^{13} \mathrm{BES}$, Area Trends in Employment and Unemployment, January 1965, p. 8; February 1965, p. 11 ; and March 1965, p. 8.

"BES, Area Trends, January 1965, p. 32; March 1965, p. 40; and May 1965, p. 42.
1964 to March 1965 period that interviews with the Walter Baker workers were obtained.

No extensive analysis of the jobs found by the terminated workers is made here. It should be noted, however, that those workers who found new jobs usually suffered a loss of wages and often were forced to move into less skilled lines of employment. The exceptions were the skilled maintenance men, who were not only able to maintain their previous occupation but also often moved into higher-paying jobs. Industrial mobility for the sample was very high: less than 10 percent found new jobs in the foodprocessing industry. With the exception of the skilled maintenance men, wage or salary reductions were most often related to age and duration of unemployment. Older workers were much more likely than younger workers to take a lower-paying job, if they were able to find new employment at all. It also appears that the longer a man had been unemployed, the more likely it was that he would be forced to take a lower wage and/or lower-skilled job.

It should also be noted that with the exception of those workers who found new jobs immediately and a few who were (for a variety of reasons) ineligible, the entire sample received unemployment compensation from the state for the period they were without work. The standard allowance in Massachusetts in 1964 and 1965 was $\$ 45$ a week for thirty weeks, with $\$ 6$ added for each dependent. The degree to which the unemployed worker was afforded financial protection during his period of unemployment is explored in the final section of this paper. 
Table 3. Reentry of the Displaced Workers into the Labor Market: "When Did You Begin to Look for Work When You Discovered You Would Be Laid Off by Baker?"

\begin{tabular}{|c|c|c|c|c|c|c|}
\hline \multirow{3}{*}{ Began to Look for Work: } & \multicolumn{2}{|c|}{ Sample } & \multicolumn{4}{|c|}{ Weeks of Unemployment } \\
\hline & \multirow{2}{*}{ Number } & \multirow{2}{*}{$\begin{array}{c}\text { Percent } \\
\text { of } \\
\text { Sample }\end{array}$} & \multicolumn{2}{|c|}{15 or Less } & \multicolumn{2}{|c|}{16 or More } \\
\hline & & & Number & Percent & Number & Percent \\
\hline Before the layoff. & 20 & 17.2 & 18 & 90.0 & 2 & 10.0 \\
\hline Immediately after the layoff. & 44 & 37.9 & 18 & 40.9 & 26 & 59.1 \\
\hline 1-2 weeks after the layoff. & 17 & 14.8 & 5 & 29.4 & 12 & 70.6 \\
\hline One month after the layoff. & 10 & 8.6 & 4 & 40.0 & 6 & 60.0 \\
\hline More than one month after the layoff........ & 5 & 4.3 & 1 & 20.0 & 4 & 80.0 \\
\hline Did not look for work.................. & 20 & 17.2 & 3 & 15.0 & 17 & 85.0 \\
\hline Total $\ldots \ldots \ldots \ldots \ldots \ldots \ldots \ldots$ & 116 & 100.0 & 49 & 42.2 & 67 & 57.8 \\
\hline
\end{tabular}

\section{Duration of Unemployment and}

Reentry into the Labor Market

Table 3 shows the relationship between the reentry of the terminated workers into the labor market and their unemployment experience. A word of explanation is needed concerning the use of the term "unemployment." What is actually being measured is the number of weeks without work between the date of the worker's termination and the date of his first job, or the date of his interview, if no new job was found. "Weeks without work" would be a more accurate title, but "unemployment" will be used; the reader should keep in mind the author's definition of the term.

In most cases, weeks without work and weeks of unemployment are synonymous. However, there were a number of workers who reported not looking for work after being terminated. Table 3 shows that twenty workers reported not looking for work at all after termination. These workers were, in a sense, not unemployed, if one defines unemployment to mean making an active search for work. However, these workers have not been eliminated from the succeeding analysis for at least two rea- sons. First, their removal would reduce the sample size by 17 percent without in any substantive fashion affecting the analysis. Second, the answers supplied by the workers are, obviously, less than objective and may suffer from being post hoc rationalizations. It is true that twelve of the twenty were fifty-five years old and older. However, when the reemployment experience of this group is compared to that of the twenty-seven others in the sample age fifty-five and over, it is not significantly different. This lends substance to the belief that some older workers "explained" their inability to find work by their lack of search. (Alternatively, one would have to argue that the reemployment success of older workers is not significantly affected by the intensity of their job search.) Nevertheless, if one accepts the workers' answers at face value, Table 3 does show that active reentry into the labor market and unemployment duration are related. However, it is obvious that an immediate active search was no guarantee of success. Of the forty-four workers who indicated entering the labor market immediately after layoff, almost 60 percent were unemployed for more than fifteen weeks. 


\section{Sex and Age}

The terminated workers averaged 18.6 weeks of unemployment. In contrast, the average duration for all unemployed in the United States in 1963 was 14 weeks; in 1964 the average was 13.3 weeks. ${ }^{15}$ Allowance must be made for this writer's definition of unemployment in making direct comparisons, however.

There was a marked difference in the unemployment experience of men and women. Terminated female workers averaged 24.8 weeks of unemployment, while males averaged only 16.5 weeks. It may be true that some of these women were not seeking work actively, but in fact all but three reported entering the labor market.

Almost all studies have shown that age is a critical determinant of the reemployment prospects of a displaced worker. Haber, Ferman, and Hudson, in their summary of eighteen studies of displaced workers, concluded:

Of all the status characteristics, age appears to have the greatest effect on re-employment opportunities. Many of the studies reported that the older workers have a more difficult time than the younger workers in finding new jobs. The emphasis is on youth in our changing technological system, and the aged are at a disadvantage. ${ }^{18}$

Among the terminated Walter Baker workers, those over age fifty-five averaged 23.6 weeks of unemployment. Those under twenty-five averaged only 6.0 weeks. The differences were more accentuated among females than among males. Table 4 reinforces the belief that reemployment difficulties became par-

${ }^{15}$ U.S. Bureau of the Census, Statistical $A b$ stract of the United States, 87th ed. (Washington: G.P.O., 1966), p. 220.

${ }^{10} \mathrm{Haber}$, The Impact of Technological Change, p. 24.
Table 4. Age Distribution and Unemployment.

\begin{tabular}{|c|c|c|c|c|}
\hline \multirow{3}{*}{ Age } & \multicolumn{4}{|c|}{ Weeks of Unemployment } \\
\hline & \multicolumn{2}{|c|}{15 Weeks or Less } & \multicolumn{2}{|c|}{16 Weeks or More } \\
\hline & Number & Percent & Number & Percent \\
\hline 24 or under. & 2 & 100.0 & 0 & 0.0 \\
\hline $25-34$ & 13 & 59.1 & 9 & 40.9 \\
\hline $35-44$ & 17 & 70.8 & 7 & 29.2 \\
\hline $45-54 \ldots$ & 12 & 41.4 & 17 & 58.6 \\
\hline $55-65 \ldots$ & 5 & 12.8 & 34 & 87.2 \\
\hline Total. & 49 & 42.2 & 67 & 57.8 \\
\hline
\end{tabular}

ticularly acute for those over the age of fifty-five.

\section{Dependents and Education}

There was a clear inverse relationship between number of dependents and duration of unemployment for this sample of terminated workers. Those who had no unemployment at all averaged 4.2 dependents. Those with less than sixteen weeks of unemployment had, on the average, 3.4 dependents. Those with sixteen or more weeks of unemployment averaged 2.2 dependents. The mean number of dependents for all workers in the sample was 2.7 , and it will be recalled that relocated workers averaged 3.4 dependents apiece.

About 42 percent of the sample had no dependents. About half of these persons lived alone and the other half lived with a working spouse. By comparison, only about 6 percent of the relocated workers lived alone.

Education is also related to unemployment. For terminated Walter Baker workers, those with less than twelve years of school averaged 21.2 weeks of unemployment experience. Those with twelve or more years of education averaged 15.8 weeks. Clearly, completion of a high school education made it less likely that a terminated worker would have sixteen or more weeks of unemployment. 
However, the relationship between education and unemployment is not strongly inverse. Within each broad educational group there were differences in duration of unemployment based on age and sex. Therefore, it appears that while education is a determinant of reemployment, it ranks below age and sex in terms of the strength of the relationship.

\section{Severance Pay}

The relationship between severance pay and unemployment experience has not been well explored in studies of terminated workers. Haber and his associates, in surveying the literature, concluded that "severance pay does not play a major role in re-employment." ${ }^{17}$ Most studies of terminated workers have found that they do not tend to use severance pay to help directly in their job search, for example, to undertake retraining. The majority of studies have found, as did Wilcock and Franke, that "the primary effect of severance pay seem(s) to be an easing of the financial burden in the period immediately following the plant closing." 18

This study confirms the earlier findings. About half the sample of terminated workers had used their severance pay, at least in part, to pay off accumulated debts. About 40 percent indicated that at least some of the severance pay had been used to meet living expenses in the period following termination. About 60 percent noted that they had added all or a portion of their severance allowance to their savings. This figure is deceptive, however, because many workers had received large lumpsum amounts, had deposited the amounts in their savings accounts, and then had

\footnotetext{
${ }^{17}$ Ibid., p. 24.

${ }^{15}$ Wilcock and Franke, Unwanted Workers, p. 124 .
}

drawn down the accounts over a period of time to meet living expenses. The 60 percent figure overstates the amount of real saving done as a result of the receipt of severance pay. Also, the larger the amount of severance pay, the higher the likelihood that the worker had added it to previous savings.

A number of workers, nearly 20 percent of the sample, in fact, had used at least a part of their severance allowance to take a vacation. Very few indicated that their severance pay had gone to pay off a mortgage, or even to make a single mortgage payment. Finally, only six workers had used any part of their severance pay to aid them in finding new work. These few workers had used some of their severance pay either to send out a resumé, to pay a private employment agency or, in one case, to pay for the cost of a job-training program. In sum, the Walter Baker workers tended to use their severance allowances to pay off debts and meet short-term living expenses.

Was the receipt of severance pay a help or hindrance in the terminated workers' search for new work? One of the earliest studies of displaced workers, by Clague, Couper, and Bakke, found that when displaced workers who had received severance pay were compared to those who did not, "month by month, dismissal wage workers were finding jobs about as quickly as the others. There is not ground whatever for thinking that the dismissal wage operated in any way as a drag on the workers' initiative."19 Other investigators have not been so sanguine about the effect of "dismissal wages" on job search. ${ }^{20}$

\footnotetext{
${ }^{10}$ Ewan Clague, et al., After the Shutdown (New Haven, Conn.: Institute of Human Relations, Yale University Press, 1934), p. 38.

${ }^{20}$ Haber, et al., The Impact of Technological Change, p. 24.
} 
Among the Walter Baker employees, there was a tendency for the number of weeks of unemployment to be positively correlated with level of severance pay. A relevant break appears to occur at fifteen weeks of unemployment. Those with less than sixteen weeks of unemployment averaged $\$ 1,116$ in severance pay, while those with sixteen or more weeks of unemployment averaged $\$ 1,800$.

Table 5 seems to support the proposition that severance pay acted somewhat as a hindrance on the reemployment of

Table 5. Severance Pay Distribution and Unemployment.

\begin{tabular}{rrrrrr}
\hline & \multicolumn{5}{c}{ Weeks of Unemployment } \\
Severance Pay & \multicolumn{4}{c}{15 Weeks or Less 16 Weeks or More } \\
& Number & Percent & Number & Percent \\
\hline $0-\$ 500 \ldots$ & 20 & 54.1 & 17 & 45.9 \\
$\$ 501-\$ 1,000 \ldots$ & 10 & 50.0 & 10 & 50.0 \\
$\$ 1,001-\$ 2,000 \ldots$ & 10 & 35.7 & 18 & 64.3 \\
$\$ 2,001-\$ 4,000 \ldots$ & 8 & 34.8 & 15 & 65.2 \\
More than & & & & \\
$\$ 4,000 \ldots . .$. & 1 & 12.5 & 7 & 87.5 \\
Total........ & 49 & 42.2 & 67 & 57.8 \\
\hline
\end{tabular}

the terminated workers. The relevant break occurs somewhere in the neighborhood of $\$ 1,000$ of severance pay, with those receiving less than $\$ 1,000$ tending to fall into the fifteen weeks or less category, and those receiving more than $\$ 1,000$ likely to fall into the sixteen weeks or more category. The evidence is far from conclusive, however, and regression analysis did not reveal a significant relationship between level of severance pay and duration of unemployment.

\section{Other Weekly Income: The Influence of a Working Spouse}

In addition to the receipt of severance pay, many workers reported other sources of income for their period of un- employment. The primary source of other weekly income was that received by a working spouse. About 28 percent of the terminated married male workers had a working wife. In addition, however, workers reported receiving income from such diverse sources as interest and dividends on savings and investments, rental income from owned property, and money received from relatives not in the worker's household. An attempt was made to develop an amount which represented the weekly "income" of each worker, exclusive of his own earnings from work or any unemployment compensation he might have received. The figures developed can be considered no more than estimates.

Table 6 shows that 61 percent of the sample received some weekly income in addition to what they might have earned or received in unemployment compensation. This figure includes workers who might have been receiving as little as a few dollars a week and as much as $\$ 200$ a week. There is a surprisingly clear relationship between weeks of unemployment and the percentage in each category indicating receipt of other weekly income. The table also shows that

Table 6. Other Weekly Income and Weeks of Unemployment.

\begin{tabular}{|c|c|c|c|}
\hline $\begin{array}{c}\text { Weeks of } \\
\text { Unemployment }\end{array}$ & $\begin{array}{c}\text { Number } \\
\text { of } \\
\text { Workers }\end{array}$ & $\begin{array}{l}\text { Percent } \\
\text { Indicating } \\
\text { Receipts } \\
\text { of Other } \\
\text { Income }\end{array}$ & $\begin{array}{c}\text { Mean } \\
\text { Other } \\
\text { Weekly } \\
\text { Income }\end{array}$ \\
\hline $0 \ldots$ & 11 & 27 & $\$ 6$ \\
\hline $1-5 \ldots \ldots \ldots \ldots$ & 12 & 33 & 30 \\
\hline $6-10 \ldots \ldots \ldots \ldots$ & 14 & 57 & 47 \\
\hline $11-15 \ldots \ldots \ldots \ldots$ & 12 & 50 & 25 \\
\hline $16-20 \ldots \ldots \ldots \ldots$ & 12 & 67 & 32 \\
\hline $21-25 \ldots \ldots \ldots \ldots$ & 26 & 69 & 64 \\
\hline $26-30 \ldots \ldots \ldots \ldots$ & 10 & 70 & 41 \\
\hline 31 or more...$\ldots$ & 19 & 89 & 79 \\
\hline Sample........ & 116 & 61 & 46 \\
\hline
\end{tabular}


the average amount of other weekly income received by workers in the sample was $\$ 46$. Those with fifteen or less weeks of unemployment averaged $\$ 29$ a week in other income, while those with sixteen or more weeks of unemployment averaged $\$ 59$ a week.

It is clear that other weekly income and duration of unemployment are positively related. This clearly demonstrates the influence of a working spouse on the labor market experience of the terminated worker.

\section{Seniority and Home Ownership}

The more senior worker is often the more experienced worker. His years of service indicate that he is, in a sense, a loyal worker. These attributes may make him attractive to a prospective employer. On the other hand, the more senior worker is also likely to be an older worker, and this study, as well as others, has shown that age is a handicap in gaining reemployment. Moreover, long service might work against a worker if an employer feels that it makes a worker less adaptable to a new environment and more difficult to retrain. ${ }^{21}$

Those workers with less than sixteen weeks of unemployment had, on the average, 11.2 years of seniority. Those with sixteen or more weeks of unemployment averaged 14.8 years of seniority. However, the variation in response within each unemployment category was great. A high proportion of Walter Baker workers had been hired between 1950 and 1959; 65 percent of the sample had between five and fourteen years of service. Of those who had more than fourteen years of service, 72 percent suffered more than fifteen weeks of unemployment.

\footnotetext{
IIbid., pp. 19-20.
}

The relationship between seniority and unemployment is similar to the relationship between severance pay and unemployment. This follows from the fact that the amount of severance pay received was largely a function of seniority. Hence, the two variables are very much intercorrelated $\left(\mathrm{R}^{2}=.88\right)$. However, neither variable was a significant explanatory factor of unemployment duration when linear regression analysis was applied to the data.

There was a slight tendency for homeowners to have more unemployment than renters. Of those with less than sixteen weeks of unemployment, about 45 percent were homeowners. Of those with sixteen or more weeks of unemployment, about 60 percent were homeowners. Apparently home ownership was positively but not strongly related to weeks of unemployment. It may be that home ownership is a proxy for a worker's wealth or net equity position. More affluent workers could afford to take their time about finding new employment. In any event, a homeowner may need to pay his property taxes and possibly mortgage charges but is not forced to meet a monthly rental payment and, therefore, is probably in a slightly better position than the renter in terms of the need to find new work.

\section{Regression Analysis}

Two previous studies have attempted to explain the length of unemployment of displaced workers by using multivariate analysis. A study by John W. Dorsey of workers displaced by the relocation of the Mack Truck Company from Plainfield, New Jersey, to Hagerstown, Maryland, in 1961, found five variables significantly related to reemployment success: age, skill, sex and family status, education, and area of residence of the 
displaced worker (i.e., the number of workers in a given area as a percentage of total nonagricultural employment in that area). Age was found to be quantitatively the most important explanatory variable. Severance pay was found to be not significantly related to length of unemployment. $^{22}$

A study by Palen and Fahey of displaced Studebaker workers in South Bend, Indiana, in 1964, found age and education to be the most important variables in explaining length of unemployment. Race, occupation, and income had significant regression coefficients, but proved to be of little use in explaining the variance in reemployment success of the displaced workers. ${ }^{23}$

For the present study the following variables were used in the analysis:

$\mathbf{X}_{1}=$ weeks of employment, $\mathbf{X}_{2}=$ age, $X_{3}=$ number of dependents, $X_{4}=$ other weekly income, $X_{5}=$ (0-male, 1 -female), $\mathrm{X}_{6}=$ weekly wage before termination, $\mathrm{X}_{7}=$ years of school, $\mathrm{X}_{8}=$ severance pay, and $X_{9}=$ years of seniority.

Weeks of unemployment were used as the dependent variable, and the next eight variables as the independent variables.

Table 7 shows the results of the regression analysis. It should be noted that the difficulties of data collection and the nonrandomness of the sample imply that caution should be used in interpreting the results. The selective bias on some variables (such as age and other weekly income) may be great. The

\footnotetext{
${ }^{22}$ John W. Dorsey, "The Mack Case: A Study in Unemployment," Studies in the Economics of Income Maintenance (Washington: The Brookings Institution, 1967), pp. 175-233.

${ }^{29}$ J. John Palen and Frank J. Fahey, "Unemployment and Reemployment Success: An Analysis of the Studebaker Shutdown," Industrial and Labor Relations Review, Vol. 21, No. 2 (January 1968), pp. 234-250.
}

results of the regression analysis should be seen as suggestive, rather than conclusive.

Nevertheless, the results indicate fairly conclusively that age, $\mathrm{X}_{2}$, provided the best single explanation of length of unemployment. The age variable alone explains 10.5 percent of the total observed variance in length of unemployment. ( $R^{2}$ is the coefficient of determination, adjusted for the size of the sample.) Furthermore, the regression coefficients for age in each of the eight equations in Table 7 are highly significant, in all but equation 6 at the .01 level.

The Palen and Fahey study found that age alone explained 10 percent of the variance in length of unemployment. The coefficients of the age variable were remarkably similar to those in Table 7.24

Two variables, age and number of dependents, are able to explain 16 percent of the variation in length of unemployment. Equation 2 shows that while age and unemployment are positively related, number of dependents and unemployment are inversely related. The larger the number of dependents, the shorter the period of unemployment for workers in this sample.

With the addition of other independent variables to the regression equation, a greater percentage of the observed variance in unemployment is explained. However, tests of significance reveal that the coefficients of the additional independent variables are not as powerfully related to length of unemployment as age and number of dependents. For example, when other weekly income, $\mathrm{X}_{4}$, is added to the equation, 17.4 percent of the variation in unemployment can be explained (equation 3). The coefficient of age is still significant at better than

\footnotetext{
IIbid., p. 242.
} 
Table 7. Multiple Regression Analysis.

\begin{tabular}{|c|c|c|c|c|c|c|c|c|c|c|}
\hline \multirow[b]{2}{*}{ Equation } & \multicolumn{9}{|c|}{$\begin{array}{l}\text { Coefficients of the Independent Variables } \\
\text { (standard errors in parentheses) }\end{array}$} & \multirow[b]{2}{*}{$\overline{\mathrm{R}}^{2}$} \\
\hline & Intercept & $X_{2}$ & $X_{3}$ & $X_{4}$ & $X_{5}$ & $X_{8}$ & $X_{7}$ & $X_{8}$ & $X_{0}$ & \\
\hline 1 & $\begin{array}{c}1.4194 \\
(4.4282)\end{array}$ & $\begin{array}{l}.3640 \\
(.0910)^{*}\end{array}$ & & & & & & & & .1053 \\
\hline 2 & $\begin{array}{c}8.2451 \\
(4.9012)\end{array}$ & $\begin{array}{l}.3112 \\
(.0910)^{*}\end{array}$ & $\begin{array}{l}-1.6018 \\
(.5551)^{*}\end{array}$ & & & & & & & .1593 \\
\hline 3 & $\begin{array}{c}7.2470 \\
(4.8925)\end{array}$ & $\begin{array}{l}(.2736) \\
(.0927)^{*}\end{array}$ & $\begin{array}{l}-1.2296 \\
(.5908) \dagger\end{array}$ & $\begin{array}{l}.0376 \\
(.0217) \ddagger\end{array}$ & & & & & & .1739 \\
\hline 4 & $\begin{array}{l}5.1956 \\
(4.9960)\end{array}$ & $\begin{array}{l}.2792 \\
(.0920)^{*}\end{array}$ & $\begin{array}{l}-.8691 \\
(.6223)\end{array}$ & $\begin{array}{l}.0277 \\
(.0222)\end{array}$ & $\begin{array}{l}4.5884 \\
(2.6757) \ddagger\end{array}$ & & & & & .1880 \\
\hline 5 & $\begin{array}{l}12.0580 \\
(7.8376)\end{array}$ & $\begin{array}{l}.2931 \\
(.0927)^{*}\end{array}$ & $\begin{array}{r}-.8999 \\
(.6221)\end{array}$ & $\begin{array}{l}.0252 \\
(.0223)\end{array}$ & $\begin{array}{l}3.3190 \\
(2.8967)\end{array}$ & $\begin{array}{l}-.0696 \\
(.0613)\end{array}$ & & & & .1901 \\
\hline 6 & $\begin{array}{l}18.7773 \\
(10.2337)\end{array}$ & $\begin{array}{l}.2576 \\
(.0990) \dagger\end{array}$ & $\begin{array}{l}-.9428 \\
(.6234)\end{array}$ & $\begin{array}{l}.0249 \\
(.0223)\end{array}$ & $\begin{array}{c}3.9532 \\
(2.9620)\end{array}$ & $\begin{array}{l}-.0688 \\
(.0613)\end{array}$ & $\begin{array}{l}-.4875 \\
(.4775)\end{array}$ & & & .1904 \\
\hline 7 & $\begin{array}{l}13.6643 \\
(11.5223)\end{array}$ & $\begin{array}{l}.3306 \\
(.1246)^{*}\end{array}$ & $\begin{array}{r}-1.0272 \\
(.6296)\end{array}$ & $\begin{array}{l}.0235 \\
(.0224)\end{array}$ & $\begin{array}{c}4.1191 \\
(2.9679)\end{array}$ & $\begin{array}{l}-.0246 \\
(.0765)\end{array}$ & $\begin{array}{l}-.5680 \\
(.4849)\end{array}$ & $\begin{array}{l}-.0010 \\
(.0011)\end{array}$ & & .1899 \\
\hline 8 & $\begin{array}{l}16.9855 \\
(11.9838)\end{array}$ & $\begin{array}{l}.3331 \\
(.1246)\end{array}$ & $\begin{array}{l}-1.0547 \\
(.6302) \ddagger\end{array}$ & $\begin{array}{l}.0196 \\
(.0227)\end{array}$ & $\begin{array}{c}4.2261 \\
(2.9696)\end{array}$ & $\begin{array}{c}-.0448 \\
(.0791)\end{array}$ & $\begin{array}{c}-.5553 \\
(.4850)\end{array}$ & $\begin{array}{c}.0003 \\
(.0018)\end{array}$ & $\begin{array}{l}-.2655 \\
(.2635)\end{array}$ & .1900 \\
\hline
\end{tabular}

*Significant at the .01 level.

†Significant at the .05 level.

\$Significant at the .10 level.

the .01 level, while the coefficient of number of dependents becomes significant at the .05 level and the coefficient of the added variable, $X_{4}$, is significant only at the .10 level. When combined with other variables, other weekly income loses all it force.

The addition of the sex variable (equation 4) allows more of the variation in unemployment to be explained but washes away a high level of significance for all but $\mathrm{X}_{2}$, age. The addition of other variables does little to increase the amount of variance explained.

Like Dorsey, the present study did not find severance pay, $\mathrm{X}_{8}$, to be significantly related to length of unemployment. Notice that the sign of the coefficient changes from equation 7 to equation 8. Unlike both Dorsey and Palen and Fahey, this writer did not find education to be significantly related to our dependent variable.
On the one hand, the fact that a fairly meaningful regression can be obtained with $\mathbb{R}^{2}$ no higher than about .19 indicates that a large number of factors possibly important in explaining the reemployment experience of the terminated workers have not been uncovered. Any individual's success in gaining new employment is undoubtedly the result of a complex set of economic, environmental, and behavioral factors. In this sense, the application of regression analysis yields disappointing results.

On the other hand, regression analysis strongly reinforces the finding that age is a critical barrier to the reemployment of terminated or displaced workers. It also suggests that sex, alternative income sources, and family size are additional factors which must be considered. Finally, it supports the belief that large amounts of severance pay affect the displaced worker's job search in a minimal way. 


\section{Financial Protection for the Unemployed}

The weekly income of workers in the sample was abnormally high in the year or so prior to their displacement. The primary reason for this was the unusual amount of overtime available to workers in the period preceding the plant closing. Also, collective bargaining negotiations with the Butcher Workmen in the summer of 1963 had resulted in a large wage increase for the workers.

The corporation granted the union demands in large part to insure labor peace over the period of the plant closing and to prevent worker attrition from rising to undesired levels. It is likely that the Walter Baker workers were overpaid, in the marginal productivity sense, in the year prior to their termination. Averaging the income of the terminated workers over a threeyear period, say 1963 to 1965 , including their unemployment compensation and severance pay, probably would still put them in a high earnings position relative to other comparable groups of workers.

The financial protection offered the terminated workers was substantial by any criteria. The average wage of the terminated worker in 1963 (prior to the increase in earnings opportunities brought about in the final year of the plant's operation) was about $\$ 100$ a week; the average severance pay received by the terminated workers was $\$ 1,500$. If the average worker was without work for about nineteen weeks, about $\$ 80$ in severance pay could be used by the worker in each week of his unemployment, and $\$ 1,500$ would be exhausted in the nineteenth week. The average worker had about two dependents, and so would receive $\$ 57$ a week in unemployment compensation for thirty weeks. The average worker, unemployed for nineteen weeks, could count on $\$ 137$ a week in income solely from unemployment compensation and severance pay. Adding the $\$ 46$ figure received by the worker from other sources, one finds that, on the average, a worker unemployed for nineteen weeks had at his disposal $\$ 183$ a week.

Of course, the above calculations are based on averages and cannot take account of the uncertainty or the hardship which occurred in individual cases. At the same time, the waste of productive resources, which resulted from real unemployment among those terminated, from the movement out of the labor market by discouraged job seekers, and from movement into inferior positions which did not tap the full productive potential of a few workers, should not be neglected in estimating the extent of the social problem resulting from the plant shutdowns. In many cases the short-run problems the workers faced in the period following their termination were probably not as great as the longrun problems they would face after their severance pay and unemployment benefits were exhausted and after they found themselves holding down a lower-paying job than they had before the plant shutdown.

\section{Conclusion}

This article has discussed the use of an interplant-transfer system by the General Foods Corporation when it closed four plants and relocated their facilities to a new plant in Dover, Delaware. Two main questions have been analyzed. Which workers were most likely to transfer to the new plant? Among the terminated workers, which workers had the most difficult time finding new employment? It turns out that the 
answers to these questions describe two different sets of workers with nearly (but not completely) opposite characteristics. Workers likely to relocate differed from workers suffering difficult reemployment experiences on such factors as age, sex, education, and family status. They overlapped on only a few items, for example, home ownership.

If one can be permitted to generalize, the following appears to be true: workers most likely to benefit from the protection of an interplant-transfer system were least likely to exercise the option of relocation. Workers who least needed the protection were most likely to move. It follows that if the General Foods experience is any guide, the use of an interplant-transfer system can serve only as a limited way of avoiding the hardship of worker displacement after plant shutdown. It would be better from the viewpoint of the workers affected by plant shutdowns to offer them greater protection for the period following their displacement, rather than to devote corporate resources to the enhancement of relocation opportunities. In particular, in such situations, companies and unions should devise special policies to handle the problem of the displaced older worker in the labor market. For example, extension of company-supported health insurance beyond termination would be a particularly valuable form of protection for the older worker.
On the other hand, the interplanttransfer system enabled the company to achieve several of its objectives over the relocation period. First, it guaranteed the company an adequate supply of labor (particularly skilled labor) at the new plant. General Foods overestimated labor recruitment difficulties in Dover. Nevertheless, there were certain grades of skilled labor in short supply, and the company's relocation policies helped forestall potential shortages. Second, as an outgrowth of its relocation policies, the company helped to insure an orderly transition to the new plant without any diminution in the supply of its products to grocery shelves. Third, the company believes it enhanced its reputation as an "enlightened" employer. Surveys of both relocated and terminated workers indicated their general satisfaction with the company's innovative efforts. Even local community reaction was favorable to the departing company. All of this is not unimportant to a company dependent on the good will of a consumer public. Finally, management believes the benefits the company received through use of the interplanttransfer system far exceeded the costs. The gross cost was $\$ 1.2$ million. The cost, net of severance allowances the company would have been committed to pay relocated workers, was $\$ 400,000$, or under $\$ 1,000$ per relocated worker. 
Copyright of Industrial \& Labor Relations Review is the property of Cornell University. The copyright in an individual article may be maintained by the author in certain cases. Content may not be copied or emailed to multiple sites or posted to a listserv without the copyright holder's express written permission. However, users may print, download, or email articles for individual use. 